\title{
The re-emergence of highly pathogenic avian influenza H7N9 viruses in humans in mainland China, 2019
}

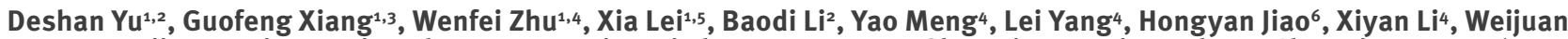

Huang $^{4}$, Hejiang Wei ${ }^{4}$, Yanping Zhang ${ }^{7}$, Yan Hai ${ }^{5}$, Hui Zhang ${ }^{2}$, Hua Yue ${ }^{5}$, Shumei Zou ${ }^{4}$, Xiang Zhao ${ }^{4}$, Chao $\mathrm{Li}^{7}$, Deng Ao ${ }^{6}, \mathrm{Ye} \mathrm{Zhang}^{4}$,

Minju Tan', Jia Liu4, Xuemei Zhang6, George F. Gao, ${ }^{4,7}$, Lei Meng ${ }^{2,8}$, Dayan Wang ${ }^{4,8}$

1. These authors contributed equally in this study as first authors

2. Gansu Provincial Center for Disease Control and Prevention, Lanzhou China

3. Jiuquan Center for Disease Control and Prevention, Jiuquan, China

4. National Institute for Viral Disease Control and Prevention, Chinese Center for Disease Control and Prevention; WHO Collaborating Center for Reference and Research on Influenza; Key Laboratory for Medical Virology, National Health Commission, Beijing, China

5. Inner Mongolia Center for Disease Control and Prevention, Hohehot, China

6. Alasan League Center for Disease Control and Prevention, Alasan, China

7. Chinese Center for Disease Control and Prevention, Beijing, China

8. These authors contributed equally as last authors in this study

Correspondence: Dayan Wang (dayanwang@cnic.org.cn)

Citation style for this article:

Yu Deshan, Xiang Guofeng, Zhu Wenfei, Lei Xia, Li Baodi, Meng Yao, Yang Lei, Jiao Hongyan, Li Xiyan, Huang Weijuan, Wei Hejiang, Zhang Yanping, Hai Yan, Zhang Hui, Yue Hua, Zou Shumei, Zhao Xiang, Li Chao, Ao Deng, Zhang Ye, Tan Minju, Liu Jia, Zhang Xuemei, Gao George F., Meng Lei, Wang Dayan. The re-emergence of highly pathogenic avian influenza H7N9 viruses in humans in mainland China, 2019. Euro Surveill. 2019;24(21):pii=1900273. https://doi.org/10.2807/1560-7917. ES.2019.24.21.1900273

Article submitted on 06 May 2019 / accepted on 23 May 2019 / published on 23 May 2019

After no reported human cases of highly pathogenic avian influenza (HPAI) $\mathrm{H} 7 \mathrm{~N} 9$ for over a year, a case with severe disease occurred in late March 2019. Among $\mathrm{HPAl} \mathrm{H}_{7} \mathrm{~N} 9$ viral sequences, those recovered from the case and from environmental samples of a poultry slaughtering stall near their home formed a distinct clade from 2017 viral sequences. Several mutations possibly associated to antigenic drift occurred in the haemagglutinin gene, potentially warranting update of $\mathrm{H} 7 \mathrm{~N} 9$ vaccine strains.

Since March 2013, influenza $\mathrm{A}\left(\mathrm{H}_{7} \mathrm{~N} 9\right)$ viruses have caused five epidemic waves of zoonotic infections with a large number of reported human cases $(1,567$ in total up to February 2018). The first wave lasted until September 2013, and the following four occurred annually between October and September of the next year from $2013 / 14$ to $2016 / 17$. During the fifth wave in $2016 / 17$, the emergence of highly pathogenic avian influenza (HPAl) $\mathrm{H}_{7} \mathrm{~N} 9$ viruses raised wide global concern [1]. Compared to low pathogenic avian influenza (LPAI) $\mathrm{A}\left(\mathrm{H}_{7} \mathrm{~N} 9\right)$ viruses, $\mathrm{HPAl} \mathrm{H}_{7} \mathrm{~N} 9$ viruses maintained the capacity to bind both human and avian receptors [2] and unreduced transmissibility in mammalian animal models, but exhibited higher virulence and broader tissue tropism [3-5]. Subsequent to 31 human HPAI $\mathrm{H}_{7} \mathrm{~N} 9$ cases being reported in China in the fifth wave, their numbers decreased dramatically from October 2017, with only one additional HPAI H7N9 human case up to February 2018. These 32 latest human cases covered nine provinces of China. During the following 14 months, neither LPAI $\mathrm{H}_{7} \mathrm{~N} 9$ nor HPAI $\mathrm{H}_{7} \mathrm{~N} 9$ was reported in humans in the country. Several HPAI $\mathrm{H}_{7} \mathrm{~N}_{9}$ outbreaks occurred in poultry, with the latest in March 2019 in peacocks in Liaoning province (http://www. moa.gov.cn/).

In late March 2019, a person in Inner Mongolia, China, presenting with severe pneumonia and respiratory failure was confirmed with HPAI H7N9. The re-emergence of a human HPAI $\mathrm{H}_{7} \mathrm{~N} 9$ virus infection after reports of such cases had ceased for more than a year caused high public health concerns. We hereby describe this case and analyse genome features of the viruses causing the infection and of viruses found near the case's residence.

\section{Case description}

The patient, a person in their early 80 s with underlying cardiovascular disease, lived in the Inner Mongolia Autonomous region. The first symptoms (day 1 of illness) occurred at the end of March 2019 and included chills, cough, fever $\left(39.0^{\circ} \mathrm{C}\right)$, headache, muscular soreness and shortness of breath. On day 6 of illness, the patient was admitted to a local hospital. Acute heart failure, hypertension, pneumonia, residuals of cerebral infarction and venous thrombosis were diagnosed. On day 7 , the clinical condition deteriorated markedly and the patient was transferred to a hospital in Gansu province, a province near Inner Mongolia. Based on clinical signs and computed tomography (CT) results, bilateral pneumonia and emphysema pulmonum were diagnosed. A patient's throat swab sampled in the beginning of April was positive for influenza $A\left(\mathrm{H}_{7} \mathrm{~N} 9\right)$ 
Phylogenetic analyses of the (A) haemagglutinin and (B) neuraminidase gene segments of HPAI H7N9 viruses recovered from an infected patient and from environmental samples collected nearby, Inner Mongolia Autonomous region, China, April 2019

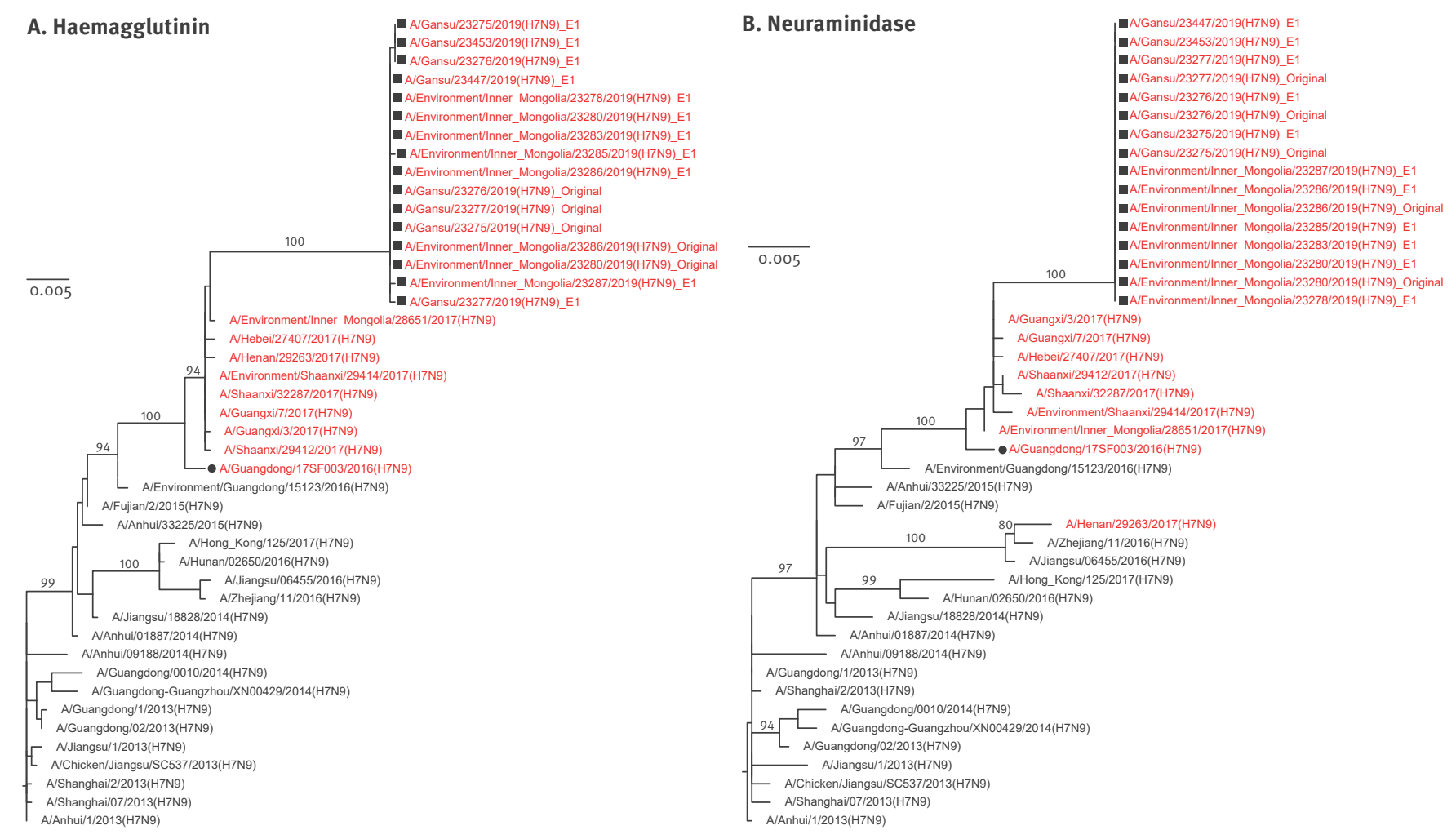

HPAI: highly pathogenic avian influenza; MEGA: Molecular Evolutionary Genetics Analysis; MUSCLE: MUltiple Sequence Comparison by Log- Expectation.

Multiple sequence alignments were performed with the MUSCLE programme using MEGA software version 7. Maximum likelihood trees on (A) haemagglutinin and (B) neuraminidase genes were conducted using the general time reversible $+\lceil$ nt substitution model with 1,000 bootstraps, respectively. HPAI $\mathrm{H} 7 \mathrm{~N} 9$ viruses are highlighted in red. The investigated viruses and the candidate $\mathrm{HPAl} \mathrm{H}_{7} \mathrm{~N} 9$ vaccine strain are shown with a solid square and circle, respectively. Bootstrap values higher than 60 are shown. Horizontal distances are proportional to genetic distance, as shown by the scale bars.

viruses. On day 19, the patient died due to secondary bacterial infections and development of multiple organ failure.

\section{Environmental investigations}

In China, regular passive surveillance of poultry related environments (including live poultry markets) has been conducted every year since 2008, by local Centers for Disease Control and Prevention (CDC). Influenza positive specimens are sent to the Chinese National Influenza Centre, Institute for Viral Disease Control and Prevention (IVDC), China CDC, for virus isolation.

Concerning the Alashan League in the Inner Mongolia Autonomous region where the patient lived, 50 to 70 environmental samples are collected annually. In 2018, all 50 such environmental samples were found to be negative for influenza $A\left(\mathrm{H}_{7} \mathrm{~N} 9\right)$ viruses. Upon the identification of the case, active surveillance was conducted. As there were two live poultry slaughtering stalls at 200 metres from the case's home, a total of 51 samples were obtained from both stalls. Of these, 22 $\mathrm{H}_{7} \mathrm{~N} 9$ positive samples were detected, all exclusively originating from the same stall. Poultry vaccination had been adopted in the region, however, investigations revealed that the particular poultry from the $\mathrm{H}_{7} \mathrm{~N} 9$ positive stall had not been vaccinated.

\section{Sequencing and identity analysis of nt sequences}

Respiratory samples had been collected from the patient on day 8, 10 and 11 of illness. Real-time reverse transcription (RT)-PCR was performed and $A\left(\mathrm{H}_{7} \mathrm{~N} 9\right)$ positive samples were propagated in the allantoic cavity of 9-10 days old specific pathogen free (SPF) embryonated chicken eggs for $48 \mathrm{~h}-72 \mathrm{~h}$ at $37^{\circ} \mathrm{C}$ in biosafety level 3 laboratory. Five virus strains were isolated from throat swab or lower respiratory tract samples, and termed as A/Gansu/23276/2019 (GS23276, H7N9), A/Gansu/23275/2019 (H7N9), A/ Gansu/23277/2019 (H7N9), A/Gansu/23447/2019 (H7N9), A/Gansu/23453/2019 (H7N9).

For the $22 \mathrm{H}_{7} \mathrm{~N} 9$ positive environmental samples, six viruses were isolated.

In order to achieve full genome sequencing of the viruses, RNA was extracted from the original samples 
Phylogenetic analyses of the (A) polymerase basic protein 2 and (B) polymerase basic protein 1 gene segments of HPAI H7N9 viruses recovered from an infected patient and from environmental samples collected nearby, Inner Mongolia Autonomous region, China, April 2019
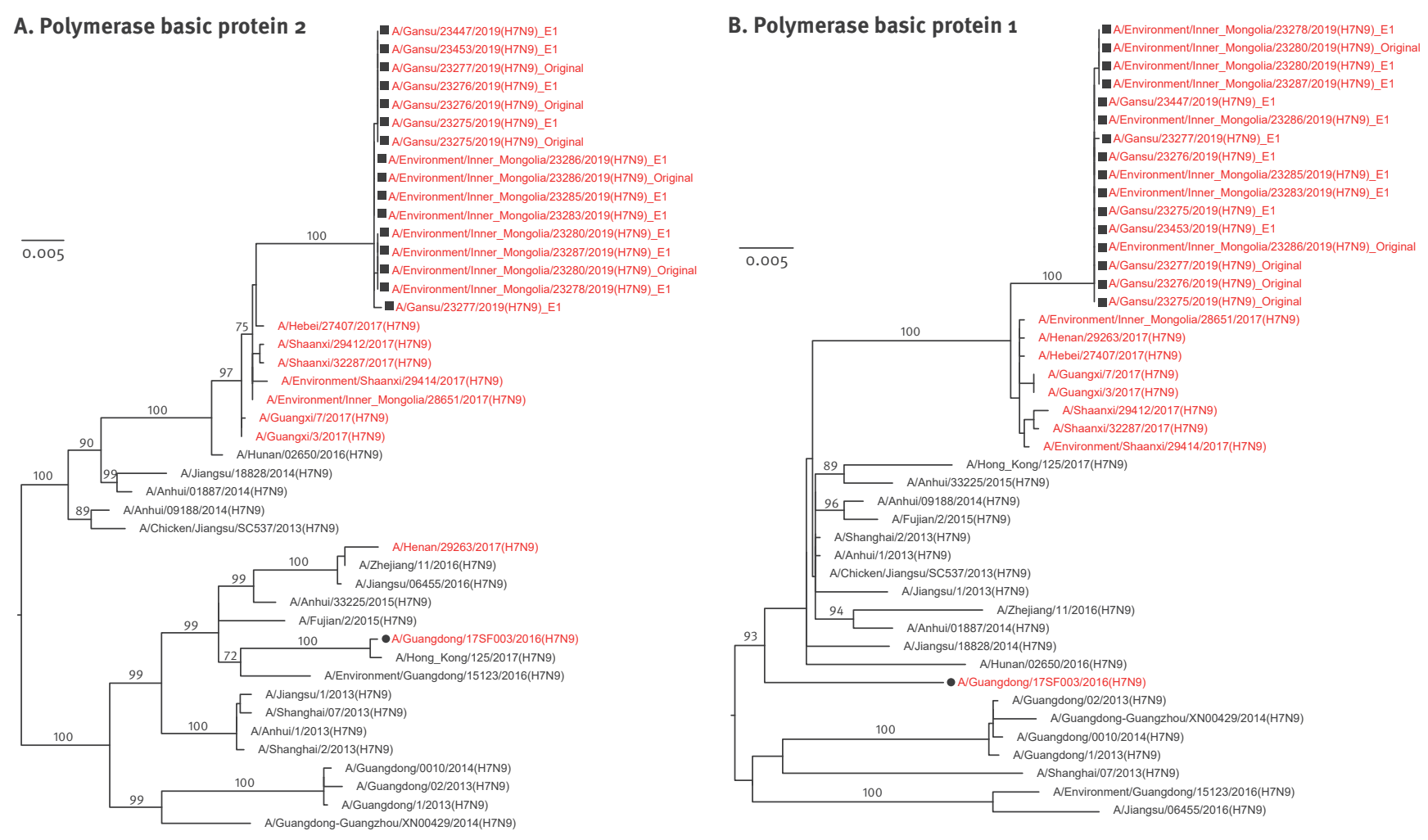

HPAI: highly pathogenic avian influenza; MEGA: Molecular Evolutionary Genetics Analysis; MUSCLE: MUltiple Sequence Comparison by Log- Expectation.

Multiple sequence alignments and maximum likelihood trees were conducted as for Figure 1 on the (A) polymerase basic protein 2 and (B) polymerase basic protein 1 genes. $\mathrm{HPAl} \mathrm{H}_{7} \mathrm{~N}$ g viruses are highlighted in red. The investigated viruses and the candidate $\mathrm{HPAl} \mathrm{H}_{7} \mathrm{~N} 9$ vaccine strain are shown with a solid square and circle, respectively. Bootstrap values higher than 60 are shown. Horizontal distances are proportional to genetic distance, as shown by the scale bars.

or isolated viruses and subjected to RT and amplification. Whole genome sequencing was implemented on the MiSeq high-throughput sequencing platform (Illumina, Inc. San Diego, California (CA)). Data analysis and genome sequences acquisition were conducted according to a previous study [6]. Full genome sequences were obtained from three original clinical samples and two original environmental samples, as well as five human isolates and six environmental isolates. The sequences were submitted to Global Initiative on Sharing All Influenza Data (GISAID) [7] with the accession number of EPI1431481-EPl1431608.

The nt sequences of the $\mathrm{H}_{7} \mathrm{~N}$ 9 viruses in this study shared $99.9 \%$ to $100 \%$ identity in each of the eight genes of the influenza virus genome, suggesting that the $\mathrm{H}_{7} \mathrm{~N} 9$ viruses in this study possess a similar genetic constellation and belong to a common evolutionary lineage. The Basic Local Alignment Search Tool (BLAST) results of the full genome nt sequences found that all eight genes of GS23276 shared the highest identity with $\mathrm{HPAl} \mathrm{H}_{7} \mathrm{~N}_{9}$ viruses isolated in 2017 , with varied identity between $97.9 \%$ to $99.1 \%$.

\section{Evolutionary analyses}

In order to analyse the relationship of these HPAI $\mathrm{H}_{7} \mathrm{~N}_{9}$ viruses genetically, viral sequences representing prototypes of each of the waves of $\mathrm{H}_{7} \mathrm{~N} 9$ outbreaks since the start of the outbreaks in 2013, as well as sequences with highest identity, were downloaded from GISAID, to generate a maximum likelihood tree using Molecular Evolutionary Genetics Analysis (MEGA) software version 7. Phylogenetic analyses of the haemagglutinin (HA) genes showed that all the HPAI $\mathrm{H}_{7} \mathrm{~N}_{9}$ viruses fall into one cluster, with the candidate vaccine strain A/ Guangdong/17SFo03/2016 (GD/SFo03, H7N9) (Figure 1A). All human and environmental HPAI $\mathrm{H}_{7} \mathrm{~N} 9$ isolates from this study grouped into a single subclade, which showed a relatively long genetic distance to other $\mathrm{HPAI} \mathrm{H}_{7} \mathrm{~N} 9$ viruses. These results indicate that the reemerged $\mathrm{HPAl} \mathrm{H}_{7} \mathrm{~N} 9$ viruses in this study may have originated from GD/SFoo3-like viruses but are divergent from the closest known ones before 2019.

Like HA genes, the other seven genes showed the same evolutionary pattern (Figure 1B, Figure 2, Figure 3. Figure 4). All eight gene segments of these 
Phylogenetic analyses of the (A) polymerase acidic protein and (B) nucleoprotein gene segments of HPAI H7N9 viruses recovered from an infected patient and from environmental samples collected nearby, Inner Mongolia Autonomous region, China, April 2019
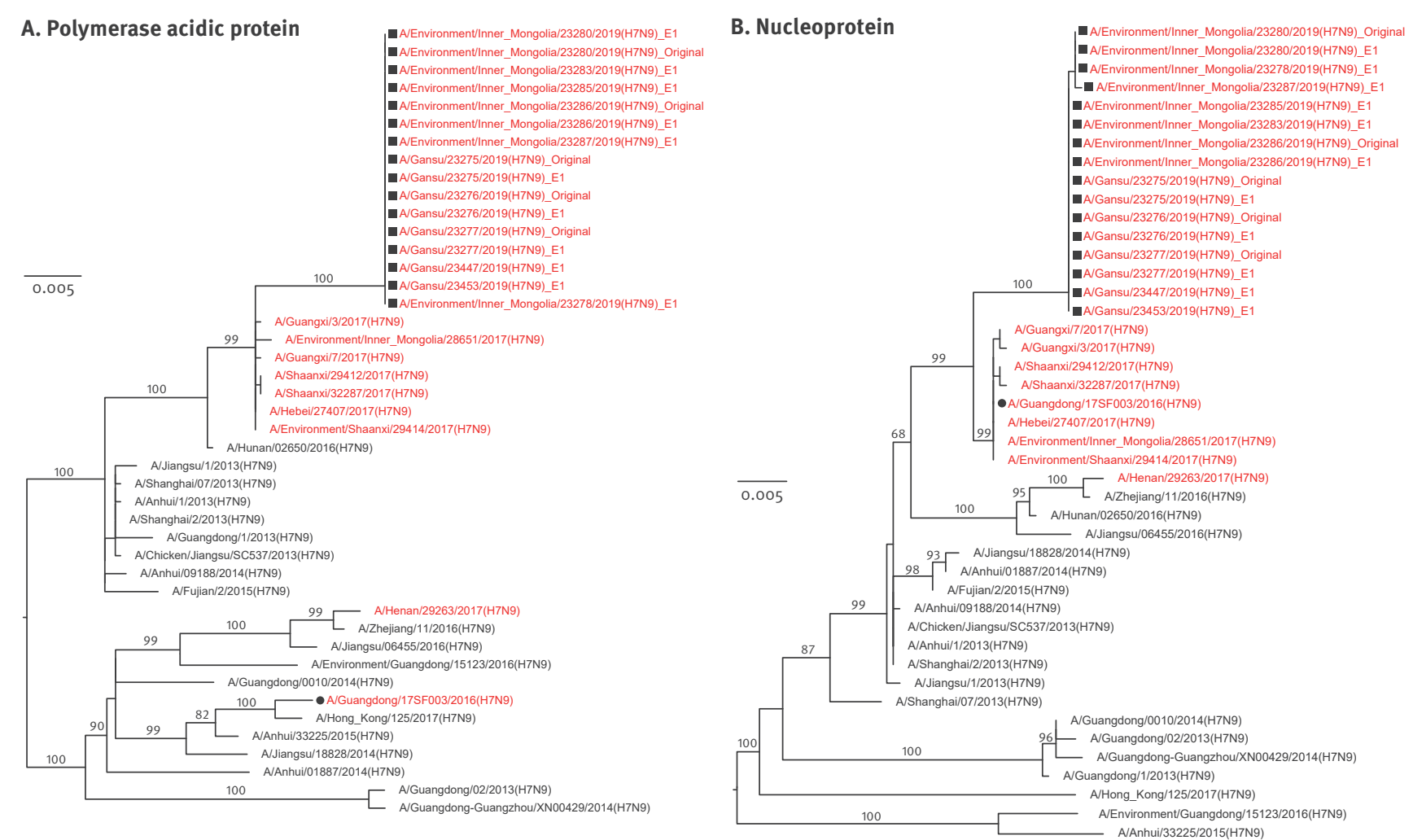

HPAI: highly pathogenic avian influenza; MEGA: Molecular Evolutionary Genetics Analysis; MUSCLE: MUltiple Sequence Comparison by Log- Expectation.

Multiple sequence alignments and maximum likelihood trees were conducted as for Figure 1 on the (A) polymerase acidic protein and (B) nucleoprotein genes. HPAI H7N9 viruses are highlighted in red. The investigated viruses and the candidate HPAI H7N9 vaccine strain are shown with a solid square and circle, respectively. Bootstrap values higher than 60 are shown. Horizontal distances are proportional to genetic distance, as shown by the scale bars.

re-emerged HPAI H7N9 isolates belonged to the same group and no re-assortment was observed.

\section{Key molecular marker analyses}

The key molecular features associated with increased virulence in mammals, mammalian transmissibility, or antiviral resistance were further determined. All HPAI $\mathrm{H}_{7} \mathrm{~N} 9$ viruses identified in this study contained a multiple basic amino acid motif (PEVPKRKRTAR.G) at the HA gene cleavage site, which is identical to the cleavage site of the candidate vaccine strain $\mathrm{GD} / \mathrm{SFo03}$, and indicates high pathogenicity in poultry. Comparison of the HA1 proteins of these viruses with the GD/SFoo3 led to identify 15 substitutions (Table 1 and Figure 5). Among them, R47K, G114R, $\mathrm{V}_{125} \mathrm{~T} / \mathrm{A}$, and $\mathrm{S}_{134} \mathrm{P}\left(\mathrm{H}_{7}\right.$ numbering) were the previously reported immune escape mutations $[8,9]$, indicating the possible antigenic variation of the re-emerged $\mathrm{HPAI} \mathrm{H}_{7} \mathrm{~N}$ 9 viruses.

All eight $\mathrm{H}_{7} \mathrm{~N} 9$ environmental virus sequences had ${ }_{125} \mathrm{~T}$ in $\mathrm{HA}$, while five of eight human viruses had $125 \mathrm{~A}$ (loss of glycosylation), indicating a human adaptation potential of this substitution [10]. The A151T mutation, which may add a new potential glycosylation motif at
N149 was present in all viruses found in this report [11]. Besides, the substitution $\mathrm{G} 177 \mathrm{~V}$ was detected in HA protein, suggesting their increased affinities to human type receptors [12]. HA Q217L has been shown to be associated with increased binding to human-like $a_{2}, 6$ receptors. All the environment- and human-origin viruses in this study had the more avian-like $Q$ at 217. The amino acid $627 \mathrm{~K}$ in $\mathrm{PB} 2$ protein, which has been suggested to increase virulence in mammalian models [13], occurred in all the re-emerged viruses derived from the case, but was not detected in any of the environmental viruses. No reported substitutions associated with drug resistance in the $\mathrm{N} 9$ protein occurred, indicating the sensitivity of the viruses to neuraminidase inhibitors [14]. However, the S31N substitution in the $M_{2}$ protein indicated their resistance to adamantine [15] (Table 2). The 12 residues truncation in the C-terminus of the NS1 protein of these viruses was also observed in $\mathrm{H}_{7} \mathrm{~N} 9$ sequences in 2017.

\section{Discussion}

Among zoonotic influenza $A$ viruses, influenza $A\left(\mathrm{H}_{7} \mathrm{~N} 9\right)$ viruses have caused a large number of reported human infections. As one of the strategies for $\mathrm{H}_{7} \mathrm{~N} 9$ prevention 
Phylogenetic analyses of the (A) matrix protein and (B) non-structural protein gene segments of HPAI H7N9 viruses recovered from an infected patient and from environmental samples collected nearby, Inner Mongolia Autonomous region, China, April 2019

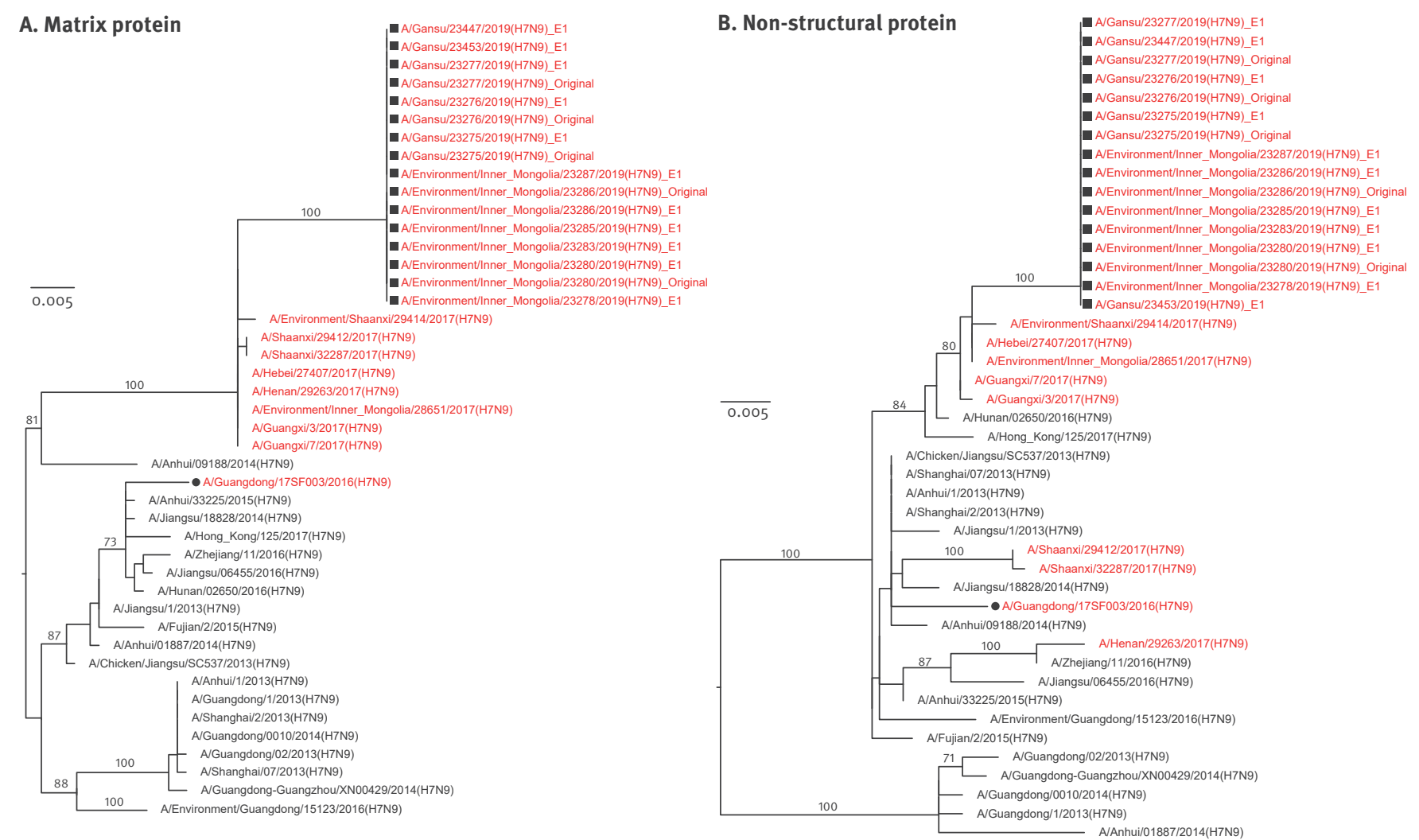

HPAI: highly pathogenic avian influenza; MEGA: Molecular Evolutionary Genetics Analysis; MUSCLE: MUltiple Sequence Comparison by Log- Expectation.

Multiple sequence alignments and maximum likelihood trees were conducted as for Figure 1 on the (A) matrix protein and (B) non-structural protein genes. HPAl $\mathrm{H} 7 \mathrm{~N}$ g viruses are highlighted in red. The investigated viruses and the candidate $\mathrm{HPAl}$ H7No vaccine strain are shown with a solid square and circle, respectively. Bootstrap values higher than 60 are shown. Horizontal distances are proportional to genetic distance, as shown by the scale bars.

and control, vaccination with an $\mathrm{H}_{5} / \mathrm{H}_{7}$ bivalent influenza vaccine was adopted in poultry in mainland China since September 2017. It has been reported that vaccination has resulted in reduced isolation rate of $\mathrm{H}_{7} \mathrm{~N}_{9}$ viruses in poultry by $93.3 \%$ [16]. No $\mathrm{H}_{7} \mathrm{~N} 9$ human cases was reported since February 2018. However, in late March 2019, we identified one HPAI H7Ng human case with fatal outcome, and HPAI $\mathrm{H}_{7} \mathrm{~N} 9$ viruses with high genome identity to those of the case were detected from environmental samples. Together, these HPAI $\mathrm{H}_{7} \mathrm{~N} 9$ viruses formed a subclade which exhibited a long genetic distance to the previously reported HPAI $\mathrm{H}_{7} \mathrm{~N}_{9}$ viruses (Figure 1). This suggests that $\mathrm{H}_{7} \mathrm{~N}_{9}$ viruses might still circulate in poultry at a low level in limited locations. In addition, several immune escape mutations, which had not been detected in previously reported HPAI H7N9 viruses, occurred in the HA1 proteins of these viruses (Table 1). The antigenic features of these HPAI $\mathrm{H}_{7} \mathrm{~N}$ 9 viruses may differ from the current $\mathrm{HPAl} \mathrm{H}_{7} \mathrm{~N} 9$ candidate vaccine strain. Phenotypic features, including antigenic characterisations and receptor binding profiles, need to be investigated in further studies. In conclusion, the detection of this HPAI H7 $\mathrm{N}_{9}$ in a human raises a concern for the virus surveillance in both human and avian species, and reminds us that there is still a long way to go to control $\mathrm{H}_{7} \mathrm{~N}_{9}$ viruses. 


\section{TABLE 1}

Mutations in haemagglutinin 1 of viral sequences recovered from an infected patient and from environmental samples collected nearby, compared to candidate vaccine strain A/Guangdong/17SF003/2016(H7N9), Inner Mongolia Autonomous region, China, April 2019a

\begin{tabular}{|c|c|c|c|c|c|c|c|c|c|c|c|c|c|c|c|c|}
\hline \multirow{2}{*}{ Strain name } & \multirow{2}{*}{ Passage } & \multicolumn{15}{|c|}{ Sites number ( $\mathrm{H}_{7}$ numbering) } \\
\hline & & 9 & 22 & $47^{b}$ & 71 & 78 & $114^{b}$ & 116 & $125^{b}$ & $134^{\mathrm{b}}$ & 151 & 163 & 169 & 184 & 261 & 301 \\
\hline A/Guangdong/17SFo03/2016(H7N9) & E1 & A & $\mathrm{R}$ & $\mathrm{R}$ & $\mathrm{E}$ & I & G & $\mathrm{T}$ & V & S & A & $\mathrm{K}$ & I & K & $\mathrm{R}$ & K \\
\hline A/Gansu/23277/2019(H7N9) & Original & $\mathrm{S}$ & $\mathrm{K}$ & $\mathrm{K}$ & K & $\mathrm{v}$ & $\mathrm{R}$ & K & $\mathrm{T}$ & $\mathrm{P}$ & $\mathrm{T}$ & $\mathrm{R}$ & $\mathrm{v}$ & $\mathrm{R}$ & G & $\mathrm{R}$ \\
\hline A/Gansu/23276/2019(H7N9) & Original & $\mathrm{S}$ & $\mathrm{K}$ & $\mathrm{K}$ & K & $\mathrm{v}$ & $\mathrm{R}$ & K & $\mathrm{A} / \mathrm{T}$ & $\mathrm{P}$ & $\mathrm{T}$ & $\mathrm{R}$ & $\mathrm{V}$ & $\mathrm{R}$ & G & $\mathrm{R}$ \\
\hline $\mathrm{A} /$ Gansu/23275/2019(H7N9) & Original & $\mathrm{S}$ & K & K & K & $\mathrm{v}$ & $\mathrm{R}$ & K & $\mathrm{A} / \mathrm{T}$ & $\mathrm{P}$ & $\mathrm{T}$ & R & $\mathrm{v}$ & $\mathrm{R}$ & $\mathrm{G}$ & $\mathrm{R}$ \\
\hline A/Gansu/23277/2019(H7N9) & E1 & $\mathrm{S}$ & K & K & K & $\mathrm{v}$ & $\mathrm{R}$ & $\mathrm{E}$ & $\mathrm{T}$ & $P$ & $\mathrm{~T}$ & $\mathrm{R}$ & $\mathrm{V}$ & $\mathrm{R}$ & $\mathrm{G}$ & $\mathrm{R}$ \\
\hline $\mathrm{A} /$ Gansu/23276/2019(H7N9) & $\mathrm{E}_{1}$ & $\mathrm{~S}$ & $\mathrm{~K}$ & $\mathrm{~K}$ & K & $\mathrm{v}$ & $\mathrm{R}$ & $\mathrm{K}$ & A & $P$ & $\mathrm{~T}$ & $\mathrm{R}$ & $\mathrm{V}$ & $\mathrm{R}$ & G & $R$ \\
\hline A/Gansu/23275/2019(H7N9) & E1 & $\mathrm{S}$ & K & K & K & $\mathrm{V}$ & $\mathrm{R}$ & $\mathrm{K}$ & A & $P$ & $\mathrm{~T}$ & $\mathrm{R}$ & $\mathrm{V}$ & $\mathrm{R}$ & G & $R$ \\
\hline $\mathrm{A} / \mathrm{Gansu} / 23447 / 2019\left(\mathrm{H}_{7} \mathrm{~N} 9\right)$ & E1 & $\mathrm{S}$ & $\mathrm{K}$ & $\mathrm{K}$ & $\mathrm{K}$ & $\mathrm{v}$ & $R$ & $\mathrm{~K}$ & $\mathrm{~T}$ & $P$ & $\mathrm{~T}$ & $\mathrm{R}$ & $\mathrm{V}$ & $\mathrm{R}$ & G & $\mathrm{R}$ \\
\hline $\mathrm{A} / \mathrm{Gansu} / 23453 / 2019\left(\mathrm{H}_{7} \mathrm{~N}_{9}\right)$ & E1 & $\mathrm{S}$ & K & K & K & $\mathrm{V}$ & $\mathrm{R}$ & K & A & $P$ & $\mathrm{~T}$ & $\mathrm{R}$ & $\mathrm{v}$ & $\mathrm{R}$ & $\mathrm{G}$ & $\mathrm{R}$ \\
\hline $\begin{array}{l}\text { A/Environment/Inner } \\
\text { Mongolia/23280/2019 }\left(\mathrm{H}_{7} \mathrm{~N} 9\right)\end{array}$ & Original & $S$ & $\mathrm{~K}$ & $\mathrm{~K}$ & $\mathrm{~K}$ & $\mathrm{~V}$ & $\mathrm{R}$ & $\mathrm{K}$ & $\mathrm{T}$ & $P$ & $\mathrm{~T}$ & $\mathrm{R}$ & V & $R$ & G & $\mathrm{R}$ \\
\hline $\begin{array}{l}\text { A/Environment/Inner } \\
\text { Mongolia/23286/2019 }\left(\mathrm{H}_{7} \mathrm{Ng}\right)\end{array}$ & Original & $S$ & $\mathrm{~K}$ & $\mathrm{~K}$ & $\mathrm{~K}$ & V & $R$ & $\mathrm{~K}$ & $\mathrm{~T}$ & $P$ & $T$ & $\mathrm{R}$ & V & $\mathrm{R}$ & $\mathrm{G}$ & $R$ \\
\hline $\begin{array}{l}\text { A/Environment/Inner } \\
\text { Mongolia/23287/2019(H7N9) }\end{array}$ & E1 & $\mathrm{S}$ & K & $\mathrm{K}$ & $\mathrm{K}$ & $\mathrm{V}$ & $\mathrm{R}$ & K & $\mathrm{T}$ & $P$ & $\mathrm{~T}$ & $\mathrm{R}$ & $\mathrm{V}$ & $\mathrm{R}$ & G & $\mathrm{R}$ \\
\hline $\begin{array}{l}\text { A/Environment/Inner } \\
\text { Mongolia/23286/2019 }\left(\mathrm{H}_{7} \mathrm{~N} 9\right)\end{array}$ & E1 & $S$ & $\mathrm{~K}$ & $\mathrm{~K}$ & $\mathrm{~K}$ & $\mathrm{~V}$ & $\mathrm{R}$ & $\mathrm{K}$ & $\mathrm{T}$ & $P$ & $\mathrm{~T}$ & $\mathrm{R}$ & $\mathrm{V}$ & $\mathrm{R}$ & $\mathrm{G}$ & $R$ \\
\hline $\begin{array}{l}\text { A/Environment/Inner } \\
\text { Mongolia/23285/2019(H7N9) }\end{array}$ & $\mathrm{E}_{1}$ & $S$ & $\mathrm{~K}$ & $\mathrm{~K}$ & $\mathrm{~K}$ & $\mathrm{~V}$ & $R$ & $\mathrm{~K}$ & $\mathrm{~T}$ & $P$ & $\mathrm{~T}$ & $\mathrm{R}$ & V & $\mathrm{R}$ & $\mathrm{G}$ & $R$ \\
\hline $\begin{array}{l}\text { A/Environment/Inner } \\
\text { Mongolia/23283/2019(H7N9) }\end{array}$ & $\mathrm{E}_{1}$ & $S$ & $\mathrm{~K}$ & $\mathrm{~K}$ & $\mathrm{~K}$ & $\mathrm{~V}$ & $R$ & $\mathrm{~K}$ & $\mathrm{~T}$ & $P$ & $\mathrm{~T}$ & $\mathrm{R}$ & $\mathrm{V}$ & $\mathrm{R}$ & $\mathrm{G}$ & $R$ \\
\hline $\begin{array}{l}\text { A/Environment/Inner } \\
\text { Mongolia/23280/2019 }\left(\mathrm{H}_{7} \mathrm{~N} 9\right)\end{array}$ & $\mathrm{E}_{1}$ & $S$ & $\mathrm{~K}$ & K & $\mathrm{K}$ & V & $R$ & $\mathrm{~K}$ & $\mathrm{~T}$ & $P$ & $\mathrm{~T}$ & $\mathrm{R}$ & V & $\mathrm{R}$ & $\mathrm{G}$ & $R$ \\
\hline $\begin{array}{l}\text { A/Environment/Inner } \\
\text { Mongolia/23278/2019(H7N9) }\end{array}$ & $\mathrm{E}_{1}$ & $S$ & $\mathrm{~K}$ & $\mathrm{~K}$ & $\mathrm{~K}$ & V & $R$ & $\mathrm{~K}$ & $\mathrm{~T}$ & $P$ & $\mathrm{~T}$ & $\mathrm{R}$ & V & $\mathrm{R}$ & $\mathrm{G}$ & $R$ \\
\hline
\end{tabular}

NA: not applicable.

Environmental samples were collected 4 days after the first specimen was obtained from the patient.

b Previously reported immune escape mutation. 


\section{TABLE 2}

List of substitutions associated with mammalian adaption, drug resistance and virulence, in viral sequences recovered from an infected patient and from environmental samples collected nearby, Inner Mongolia Autonomous region, China, April 2019

\begin{tabular}{|c|c|c|c|c|c|}
\hline Protein & Mutation & Function & $\begin{array}{l}\text { Amino } \\
\text { acid }\end{array}$ & $\begin{array}{l}\text { Number } \\
\text { of human } \\
\text { viruses }\end{array}$ & $\begin{array}{l}\text { Number of } \\
\text { environmental } \\
\text { viruses }\end{array}$ \\
\hline \multirow{3}{*}{$\mathrm{HA}$} & \multirow{3}{*}{$\mathrm{A} 125^{\mathrm{a}}$} & \multirow{3}{*}{$\begin{array}{l}\text { Introduces a glycosylation sequon at } 123 \mathrm{~N} \text { and } \\
\text { increased avian receptor specificity [10]. }\end{array}$} & A & 3 & o \\
\hline & & & $\mathrm{T}$ & 3 & 8 \\
\hline & & & $A / T$ & 2 & 0 \\
\hline HA & $\mathrm{G}_{177} \mathrm{~V}^{\mathrm{a}}$ & Increased virus binding to human-type receptors. & V & 8 & 8 \\
\hline HA & Q217 $\mathrm{L}^{\mathrm{a}}$ & Increased virus binding to human-type receptors. & Q & 8 & 8 \\
\hline PB2 & $\mathrm{K}_{526 \mathrm{R}}$ & Enhance the $627 \mathrm{~K}$ and $701 \mathrm{~N}$ function. & R & 8 & 8 \\
\hline PB2 & M535L & $\mathrm{M}_{535} \mathrm{~L}$ and $\mathrm{K} 627 \mathrm{E}$, restored the polymerase activity. & L & 8 & 8 \\
\hline \multirow{2}{*}{ PB2 } & \multirow{2}{*}{$\mathrm{E} 627 \mathrm{~K}$} & \multirow{2}{*}{ Increased virulence in mammalian models. } & K & 8 & 0 \\
\hline & & & $\mathrm{E}$ & o & 8 \\
\hline PA & $\mathrm{K} 356 \mathrm{R}$ & $\begin{array}{l}\text { Host signature amino acids (avian to human adaptation } \\
\text { resulting in increased replication and pathogenicity in } \\
\text { mammals) }\end{array}$ & $\mathrm{R}$ & 8 & 8 \\
\hline PA & $\mathrm{S}_{409 \mathrm{~N}}$ & $\begin{array}{l}\text { Host signature amino acids (avian to human adaptation } \\
\text { resulting in increased replication and pathogenicity in } \\
\text { mammals) }\end{array}$ & $\mathrm{N}$ & 8 & 8 \\
\hline M2 & A30S & $\begin{array}{c}\text { Reduced susceptibility to licensed anti-influenza } \\
\text { medications. }\end{array}$ & S & 8 & 8 \\
\hline M2 & $\mathrm{S}_{31 \mathrm{~N}}$ & $\begin{array}{l}\text { Reduced susceptibility to licensed anti-influenza } \\
\text { medications. }\end{array}$ & N & 8 & 8 \\
\hline NS1 & $\mathrm{P}_{4} 2 \mathrm{~S}$ & Altered virulence in mice. & $\mathrm{S}$ & 8 & 8 \\
\hline NS1 & $\mathrm{N} 205 \mathrm{~S}$ & Altered antiviral response in host. & S & 8 & 8 \\
\hline NS1 & E218stop & $\begin{array}{l}\text { Truncation that removes } 12 \text { residues from C-terminus } \\
\text { with potential effect on pathogenicity [17]. }\end{array}$ & Stop & 8 & 8 \\
\hline NS2 & $\mathrm{T} 48 \mathrm{~A}$ & Altered antiviral response in host. & A & 8 & 8 \\
\hline
\end{tabular}

${ }^{\mathrm{a}} \mathrm{H} 7$ numbering. 


\section{FIGURE 5}

Structural view of mutations in the haemagglutinin 1 viral sequences recovered from a highly pathogenic avian influenza $\mathrm{A}(\mathrm{H} 7 \mathrm{~N} 9)$ infected patient and from environmental samples collected nearby, compared to candidate vaccine strain A/ Guangdong/17SF003/2016(H7N9), Inner Mongolia Autonomous region, China, April 2019

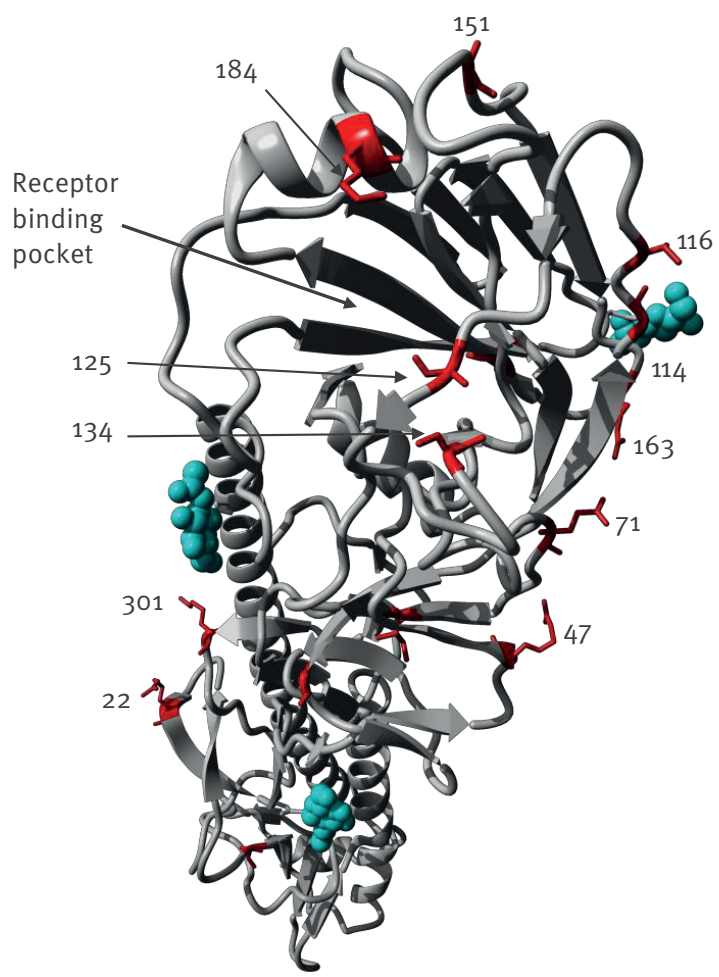

Residues at positions of mutations listed in Table 1 are shown as red sticks in the crystal structure of $\mathrm{H}_{7} \mathrm{~N} 9 \mathrm{HA}$ (PDB: $4 \mathrm{KOL}$, using YASARA). Glycosylation as seen in original structure is shown as cyan balls.

\section{Acknowledgments}

This study was supported by the National Key Research and Development Program of China (2016YFD0500208), the National Nature Science Foundation of China (31761133003) and the National Mega-projects for Infectious Diseases (2017ZX10104001002002 and 2017ZX10303401-004). The contents of this article are solely the responsibility of the authors and do not necessarily represent the views of China CDC or other organisations. We thank the GISAID Initiative and Sebastian Maurer-Stroh from BII A*STAR for providing the structural figure and discussion of mutations with FluSurver. We also gratefully acknowledge the authors, originating and submitting laboratories of the sequences from GISAID's EpiFlu Database used in the phylogenetic analysis.

\section{Conflict of interest}

None declared.

\section{Authors' contributions}

DYW designed the study. DSY, GFX, WFZ, XL, BDL, YM, LY, HYJ, XYL, WJH, HJW, YPZ, YH, HZ, HY, SMZ, XZ, CL, DA, YZ,
MJT, JL, XMZ, and LM performed the study. DYW, DSY, WFZ, LY analysed the data. GFG provided technical advice. DYW, WFZ, and LY drafted the manuscript and revised the manuscript. DSY, GFX, WFZ, and XL contributed equally to this study.

\section{References}

1. Ke C, Mok CKP, Zhu W, Zhou H, He J, Guan W, et al. Human Infection with Highly Pathogenic Avian Influenza A( $\left.\mathrm{H}_{7} \mathrm{~N}_{9}\right)$ Virus, China. Emerg Infect Dis. 2017;23(8):1332-40. https:// doi.org/10.3201/eid2308.170600 PMID: 28580899

2. Zhu W, Zhou J, Li Z, Yang L, Li X, Huang W, et al. Biological characterisation of the emerged highly pathogenic avian influenza ( $\mathrm{HPAl}) \mathrm{A}\left(\mathrm{H}_{7} \mathrm{~N} 9\right)$ viruses in humans, in mainland China, 2016 to 2017. Euro Surveill. 2017;22(19):30533. https:// doi.org/10.2807/1560-7917.ES.2017.22.19.30533 PMID: 28537546

3. Zhu W, Yang L, Shu Y. Did the Highly Pathogenic Avian Influenza A(H7N9) Viruses Emerged in China Raise Increased Threat to Public Health? Vector Borne Zoonotic Dis. 2019;19(1):22-5. https://doi.org/10.1089/vbz.2018.2299 PMID: 30222520

4. Shi J, Deng G, Kong H, Gu C, Ma S, Yin X, et al. H7N9 virulent mutants detected in chickens in China pose an increased threat to humans. Cell Res. 2017;27(12):1409-21. https://doi. org/10.1038/cr.2017.129 PMID: 29151586

5. Imai M, Watanabe T, Kiso M, Nakajima N, Yamayoshi S, Iwatsuki-Horimoto K, et al. A Highly Pathogenic Avian $\mathrm{H}_{7} \mathrm{~N} 9$ Influenza Virus Isolated from A Human Is Lethal in Some Ferrets Infected via Respiratory Droplets. Cell Host Microbe. 2017;22(5):615-626.e8. https://doi.org/10.1016/j. chom.2017.09.008 PMID: 29056430

6. Zhu W, Dong J, Zhang Y, Yang L, Li X, Chen T, et al. A Gene Constellation in Avian Influenza $\mathrm{A}\left(\mathrm{H}_{7} \mathrm{Ng}\right.$ ) Viruses May Have Facilitated the Fifth Wave Outbreak in China. Cell Rep. 2018;23(3):909-17. https://doi.org/10.1016/j. celrep.2018.03.081 PMID: 29669294

7. Shu Y, McCauley J. GISAID: Global initiative on sharing all influenza data - from vision to reality. Euro Surveill. 2017;22(13):30494. https://doi.org/10.2807/1560-7917. ES.2017.22.13.30494 PMID: 28382917

8. Henry Dunand CJ, Leon PE, Huang M, Choi A, Chromikova V, Ho IY, et al. Both Neutralizing and Non-Neutralizing Human H7No Influenza Vaccine-Induced Monoclonal Antibodies Confer Protection. Cell Host Microbe. 2016;19(6):800-13. https://doi. org/10.1016/j.chom.2016.05.014 PMID: 27281570

9. Tan GS, Leon PE, Albrecht RA, Margine I, Hirsh A, Bahl J, et al. Broadly-Reactive Neutralizing and Non-neutralizing Antibodies Directed against the $\mathrm{H}_{7}$ Influenza Virus Hemagglutinin Reveal Divergent Mechanisms of Protection. PLoS Pathog. 2016;12(4):e1005578. https://doi.org/10.1371/journal. ppat.1005578 PMID: 27081859

10. Srinivasan K, Raman R, Jayaraman A, Viswanathan K, Sasisekharan R. Quantitative description of glycan-receptor binding of influenza $\mathrm{A}$ virus $\mathrm{H} 7$ hemagglutinin. PLoS One. 2013;8(2):e49597. https://doi.org/10.1371/journal. pone.0049597 PMID: 23437033

11. Wang W, Lu B, Zhou H, Suguitan AL Jr, Cheng X, Subbarao $\mathrm{K}$, et al. Glycosylation at $158 \mathrm{~N}$ of the hemagglutinin protein and receptor binding specificity synergistically affect the antigenicity and immunogenicity of a live attenuated $\mathrm{H}_{5} \mathrm{~N}_{1}$ A/Vietnam/1203/2004 vaccine virus in ferrets. J Virol. 2010;84(13):6570-7. https://doi.org/10.1128/JVI.00221-10 PMID: 20427525

12. Shi Y, Zhang W, Wang F, Qi J, Wu Y, Song H, et al. Structures and receptor binding of hemagglutinins from human-infecting $\mathrm{H} 7 \mathrm{~N} 9$ influenza viruses. Science. 2013;342(6155):243-7. https://doi.org/10.1126/science.1242917 PMID: 24009358

13. Hatta M, Gao P, Halfmann P, Kawaoka Y. Molecular basis for high virulence of Hong Kong $\mathrm{H}_{5} \mathrm{~N}_{1}$ influenza A viruses. Science. 2001;293(5536):1840-2. https://doi.org/10.1126/ science.1062882 PMID: 11546875

14. Nguyen HT, Fry AM, Gubareva LV. Neuraminidase inhibitor resistance in influenza viruses and laboratory testing methods. Antivir Ther. 2012;17(1 Pt B):159-73. https://doi.org/10.3851/ IMP2067 PMID: 22311680

15. Lan Y, Zhang Y, Dong L, Wang D, Huang W, Xin L, et al. A comprehensive surveillance of adamantane resistance among human influenza A virus isolated from mainland China between 1956 and 2009. Antivir Ther. 2010;15(6):853-9. https://doi. org/10.3851/IMP1656 PMID: 20834097

16. Zeng X, Tian G, Shi J, Deng G, Li C, Chen H. Vaccination of poultry successfully eliminated human infection with $\mathrm{H}_{7} \mathrm{~N} 9$ 
virus in China. Sci China Life Sci. 2018;61(12):1465-73. https:// doi.org/10.1007/s11427-018-9420-1 PMID: 30414008

17. Kong W, Liu L, Wang Y, He Q, Wu S, Qin Z, et al. C-terminal elongation of $\mathrm{NS}_{1}$ of $\mathrm{H}_{9} \mathrm{~N}_{2}$ influenza virus induces a high

level of inflammatory cytokines and increases transmission.

J Gen Virol. 2015;96(Pt 2):259-68. https://doi.org/10.1099/

vir.0.071001-o PMID: 25326314

\section{License, supplementary material and copyright}

This is an open-access article distributed under the terms of the Creative Commons Attribution (CC BY 4.0) Licence. You may share and adapt the material, but must give appropriate credit to the source, provide a link to the licence and indicate if changes were made.

Any supplementary material referenced in the article can be found in the online version.

This article is copyright of the authors or their affiliated institutions, 2019. 